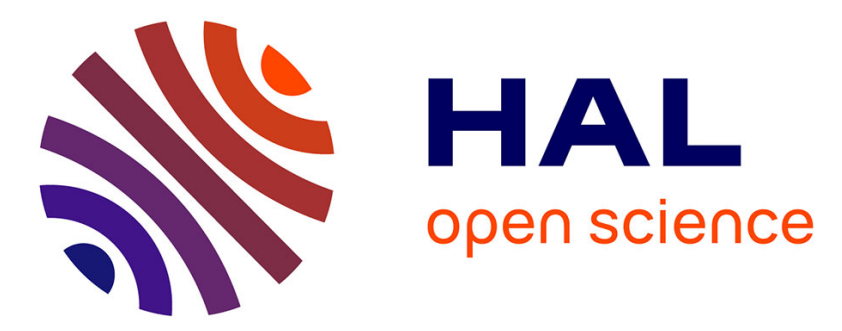

\title{
High-Strain, High-Strain Rate Deformation, Shear Localization and Recrystallization in Tantalum
}

\author{
Y. Chen, J. Lasalvia, V. Nesterenko, M. Meyers, M. Bondar, Y. Lukyanov
}

\section{To cite this version:}

Y. Chen, J. Lasalvia, V. Nesterenko, M. Meyers, M. Bondar, et al.. High-Strain, High-Strain Rate Deformation, Shear Localization and Recrystallization in Tantalum. Journal de Physique IV Proceedings, 1997, 07 (C3), pp.C3-435-C3-440. 10.1051/jp4:1997375 . jpa-00255532

\section{HAL Id: jpa-00255532 https://hal.science/jpa-00255532}

Submitted on 1 Jan 1997

HAL is a multi-disciplinary open access archive for the deposit and dissemination of scientific research documents, whether they are published or not. The documents may come from teaching and research institutions in France or abroad, or from public or private research centers.
L'archive ouverte pluridisciplinaire HAL, est destinée au dépôt et à la diffusion de documents scientifiques de niveau recherche, publiés ou non, émanant des établissements d'enseignement et de recherche français ou étrangers, des laboratoires publics ou privés. 


\title{
High-Strain, High-Strain Rate Deformation, Shear Localization and Recrystallization in Tantalum
}

\author{
Y.J. Chen**, J.C. LaSalvia**,*, V.F. Nesterenko**, M.A. Meyers****, M.P. Bondar*** and \\ Y.L Lukyanov*** \\ * Institute for Mechanics and Materials \\ ** Department of Applied Mechanics and Engineering Sciences, University of California, \\ San Diego, La Jolla, California 92093, U.S.A. \\ *** Lavrentyev Institute of Hydrodynamics, Russian Academy of Sciences, Novosibirsk 630090, Russia
}

\begin{abstract}
Tantalum tubular specimens, embedded in copper thick-wall cylinders, were collapsed quasi-uniformly by detonating the explosive in $\infty$-axial with the copper cylinder. The microstructure featured: (i) dislocations and elongated dislocation cells; (ii) subgrains; (iii) dynamically recrystallizod micrograins; and (iv) statically recrystallized grains whose grain sizes were predicted using conventional grain-growth kinetics. The evolution mechanism of the microstnucture from elongated dislocation cells, subgrains, to micrograins is proposed. Grain-scale localization was observed. Ductile fracture along shear bands was produced by the residual tensile hoop stresses near the central hole region upon unloading.

Résumé: Des échantillons tubulaires en tantale, entourés par des cylindres à paroi épaisse ont subi une implosion de façon symétrique par la détonation d'un explosif placé de façon co-axiale avec le cylindre en cuivre. La microstructure est constituée de : (i) dislocations et cellules de dislocations allongées; (ii) sous-grains; (iii) micrograins produits par recristallisation dynamique; (iv) grains générés par recristallisation statique dont la taille de grains a été prévue par la cinétique conventionnelle de croissance des grains. Un mécanisme est proposé pour l'évolution de la microstructure des cellules allongées, sous-grains, et micrograins. Une localisation de la déformation à l'échelle des grains a été observée. La rupture ductile le long des bandes de cisaillement est due aux contraintes résiduelles engendrées dans l'orifice intérieur après déchargement.
\end{abstract}

\section{INTRODUCTION}

Tantahum and its tungsten alloys are excellent for shaped charges and EFP's because of their high density, ductility, and strength. In EFP's the effective strain can be up to 10 [1], whereas in shaped charges it is even higher. The change of microstructures of tantalum in shaped-charges [2,3] and EFP's [4,5] has been studieded. A broad range of microstructures was observed: dislocation cells, sub-boundaries, and recrystallized grains. The thermomechanical conditions of shaped charges and EFP's can be simulated with experiments using hat-shaped specimens[6] and thickwall cylinders $[7,8]$. The limitation of hat-shaped specimens is the effective strain not higher than $\sim 3$. The primary microstructural changes observed were dynamic recovery and the onset of dynamic recrystallization in some isolated regions [6]. The thick-wall cylinder method enables higher strains under controlled conditions. This report describes the application of this technique to tantalum, and correlates microstructural changes with the local thermal excursion.

\section{EXPERIMENTAL PROCEDURE}

Two types of tantalum (Cabot Co.) were used: a) $\phi 155 \mathrm{~mm} \times 8 \mathrm{~mm}$ disk, described in detail by Meyers et al. [6]. The grain size is $31 \mu \mathrm{m}$. The interstitial contents are $\mathrm{C}: 60 ; 0: 70 ; \mathrm{N}: 10 ; \mathrm{H}: 4$, in ppm. b) tubes, with internal diameter of $15 \mathrm{~mm}$. The grain size is $39 \mu \mathrm{m}$. The interstitial: $\mathrm{C}: 25 ; 0: 60 ; \mathrm{N}:<10 ; \mathrm{H}:<5$, in ppm.

Figure 1 shows the schematic of the experimental setup. The specimen was embedded in a copper thick-walled cylinder. The external diameter of the specimens was $19 \mathrm{~mm}$ and the internal diameter was $11 \mathrm{~mm}$ for disks and 15 $\mathrm{mm}$ for tubes. The strain rate as a function of time varies between 1 and $3.5 \times 10^{4} \mathrm{~s}^{-1}$

\section{RESULTS AND DISCUSSION}

\subsection{Overall Microstructural Changes}

The center of the collapsed tantalum cylinder ( tube) is shown in Figure 2. The central orifice with a radius of -0.5 
$\mathrm{mm}$ is due to either jetting along the cylinder axis or to the insufficient collapse. A pattern of convergent plastic flow and radial cracks along shear localized regions can be seen. Figure 3 shows a broad variety of microstructure near the central orifice region. Grain size decreases from the initial value of $31 \mu \mathrm{m}$ to $17 \mu \mathrm{m}$ near the central orifice, indicative of recrystallization. The grain size decrease along outward radial direction is plotted in Figure 4. Two distinct areas can be seen in Figure 3: uniformly etched regions in the front of the crack tips, marked R; and elongated features marked E. The crack tips show considerable blunting with a radius of $\sim 10 \mu \mathrm{m}$, indicative of ductile fracture. Radial hardness distribution is given in Figure 5. Consistent with the microstructural changes, region $\mathbf{R}$ has higher hardness. Figure 5(b) shows two levels of hardness: heavily deformed (A) and less distorted (B). This is discussed further in Figure 10

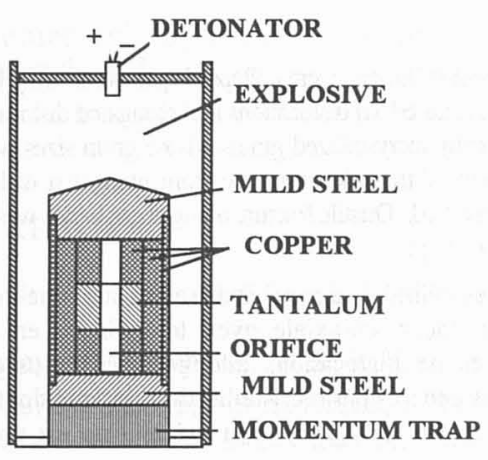

Figure 1 Experimental setup.

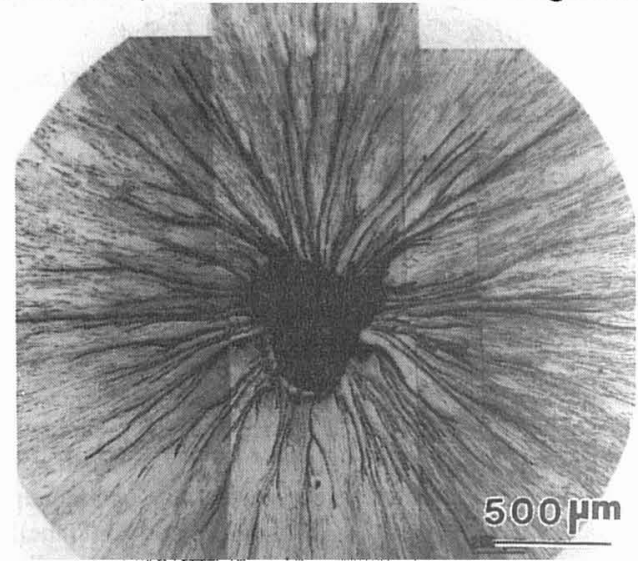

Figure 2 Collapsed cylinder showing residual central hole and radial cracks.

Meyers et al. [6] determined the quasi-static $\left(10^{-3} \mathrm{~s}^{-1}\right)$ flow stress of $300 \mathrm{MPa}$ for the tantalum disk, consistent with the initial hardness of HVN $100(980 \mathrm{MPa})$. Although this material is somewhat work-hardened and therefore the yield stress exceeds the predicted Hall-Petch value for grain size of $31 \mu \mathrm{m}$, it is possible to estimate the grain size for region R, having the hardness of HVN 200 (1960 MPa), by using Hall-Petch parameters for tantalum of $90 \leq \sigma_{0} \leq$ $210 \mathrm{MPa}$ and $9 \leq \mathrm{k} \leq 19 \mathrm{MPa} / \mathrm{mm}^{12}[9,10]$ :

$$
\sigma=\sigma_{0}+\mathrm{kd}^{-1 / 2}
$$

The predicted grain size is $\sim 0.1 \mu \mathrm{m}$, obtained by taking $k=14 \mathrm{MPa} \mathrm{mm}{ }^{1 / 2}$.

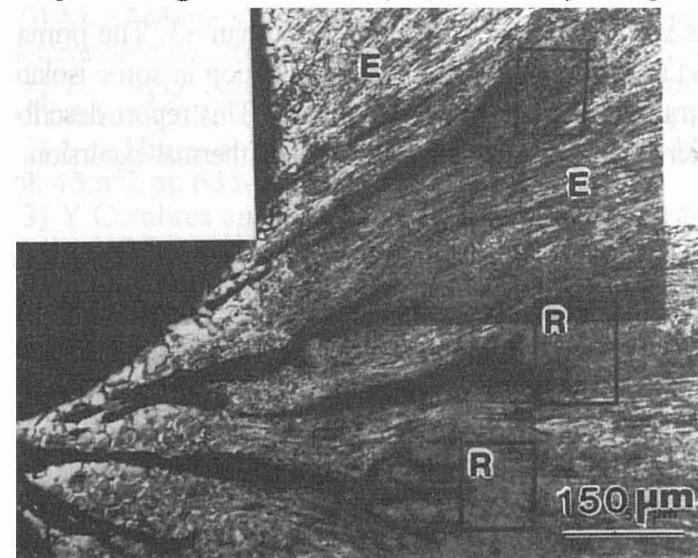

Figure 3 Microstructure in vicinity of central hole and cracks

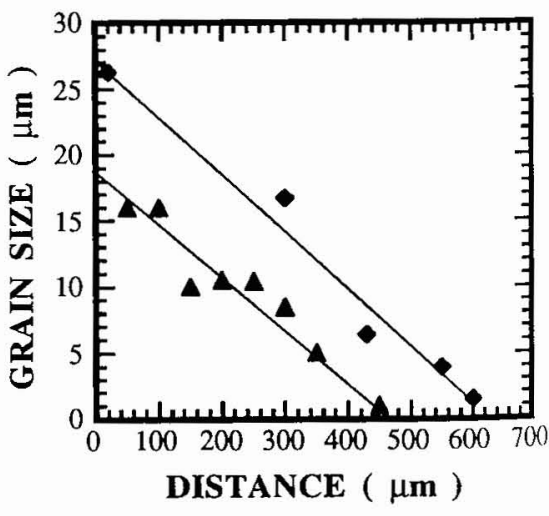

Figure 4 Radial recrystallized grain size distribution in collapsed cylinder.

Figure $6-8$ show the microstructure evolution from dislocation cells, sub-grains, to recrystallized grains. The misorientations between the elongated cells were measured to be $2^{\circ}, 6^{\circ}, 4^{\circ}$, and $3.5^{\circ}$ with respect to cell 1 (Figure (0). typical of a highly deformed structure $\left(\varepsilon_{\mathrm{ef}} \cong 2\right.$ ). Qiang et al. [1] and Murr et al. [4] observed a similar microstructure 
with misorientations between $3^{\circ}$ and $8^{\circ}$. The width of these cells is approximately $0.1-0.3 \mu \mathrm{m}$. The misorientation increases and the cell walls become sharper with the increase of plastic deformation. A similar breakup pattern was observed for copper [11]. The elongated sub-grains break up into more equiaxed grains with the grain size equal to the width of the sub-grains. This is in agreement with Hall-Patch prediction above. Gil Sevillano et al. [12] suggested this mechanism to be a characteristic of high-strain deformation. A small emerging grain can be seen in Figure 7 as indicated by arrow A. Arrow B indicates Moiré fringes suggesting a well defined boundary. In Figure 8 micrograins with size of $\sim 0.2 \mu \mathrm{m}$ can be seen very clearly with both bright and dark field images.

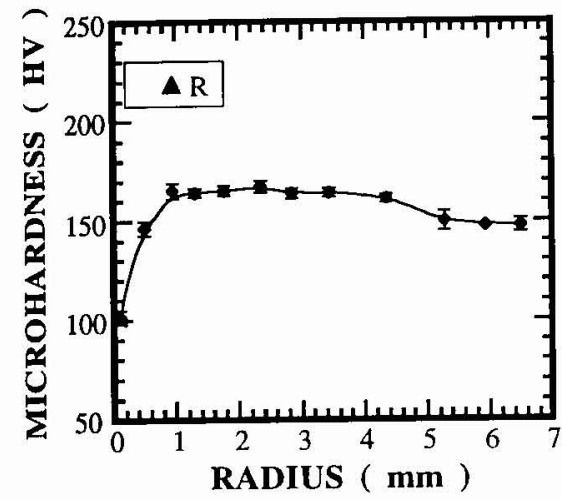

(a)

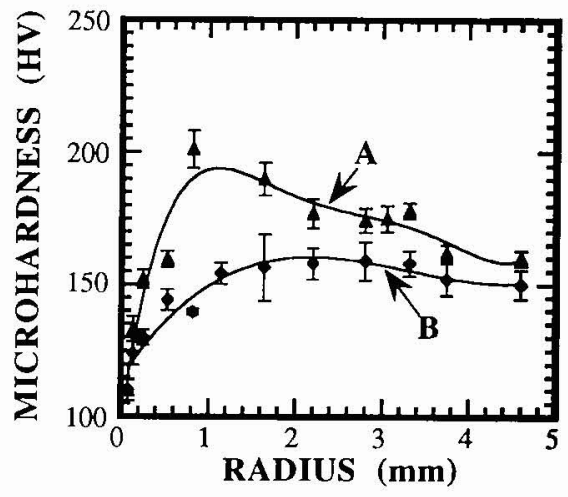

(b)

Figure 5 Radial microhardness distribution of collapsed cylinder; (a) disk specimens; (b) tube specimens.

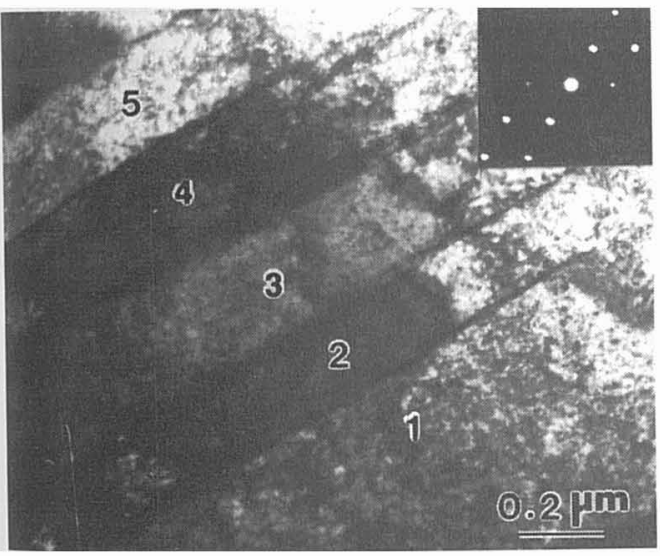

Figure 6 TEM at the region of $\sim 1.5 \mathrm{~mm}$ from center $\left(\varepsilon_{\mathrm{er}} \approx\right.$ $1.8 ; 400 \mathrm{~K})$; SAD from cell 4.

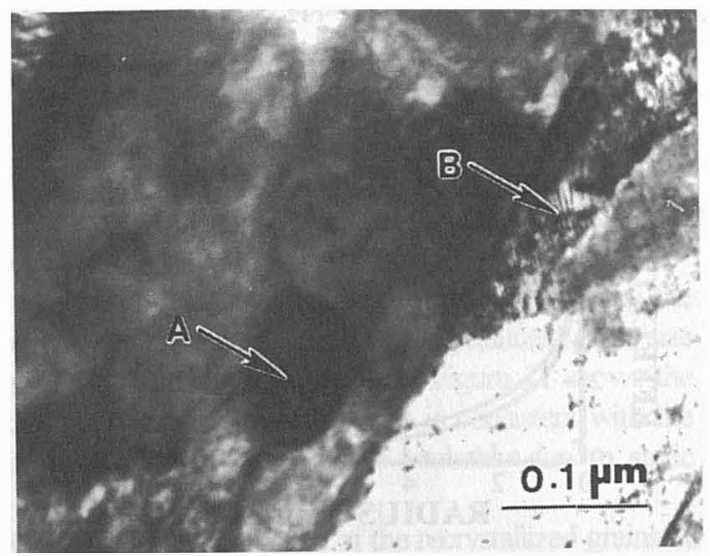

Figure 7 TEM at the adjacent region of Figure 6 showing break-up of elongated sub-grains.

\subsection{Localization of Plastic Deformation}

The peculiar feature of tantalum is that plastic deformation being localized in separate regions $(E)$ is accompanied by grains which are uniformly deformed with subsequent difference in microhardness (Figure 10). The formation of highly deformed bands juxtaposed with less deformed bands with increasing the plastic strain confirms earlier observations by Qiang et al. [1]. These highly deformed bands provide thermal fluctuations, which create periodic arrays of softened regions. Upon unloading the residual tensile stresses produce openings along these bands, and the cracks serve as markers for them (Figure 2). Upon computation, after unloading, there are residual tangential tensile stresses near the central orifice, vanishing at a radius of $\sim 3.4 \mathrm{~mm}$. This value is therefore taken as the upper bound of mode I crack length, and is consistent with the length of the cracks observed (Figure 2): their radial trajectories are $\sim 0.5 \mathrm{~mm}$ long.

Profound differences in work hardening for different crystal orientations have been found in tantalum $[13,14]$, which can lead to grain-scale localization in conjunction with texture softening. Texture softening becomes operative 
through plastic deformation due to the rotation of the grains towards orientations with larger Schmid factors.

The material is under triaxial compression during the collapse of the cylinder and individual grains undergo very large extensions due to the pure shear imparted to them. Under the action of the compressive hoop stresses, the "softer" grains will deform more, and this can lead to much more pronounced grain distortions. Thus, grain-scale inhomogeneity of plastic deformation (texture softening and anisotropy of plastic flow) is thought to be the leading cause for localization of plastic deformation in tantalum deformed at high strain rates, as indicated by Gil Sevillano et al. [12] and Meyers et al. [15].
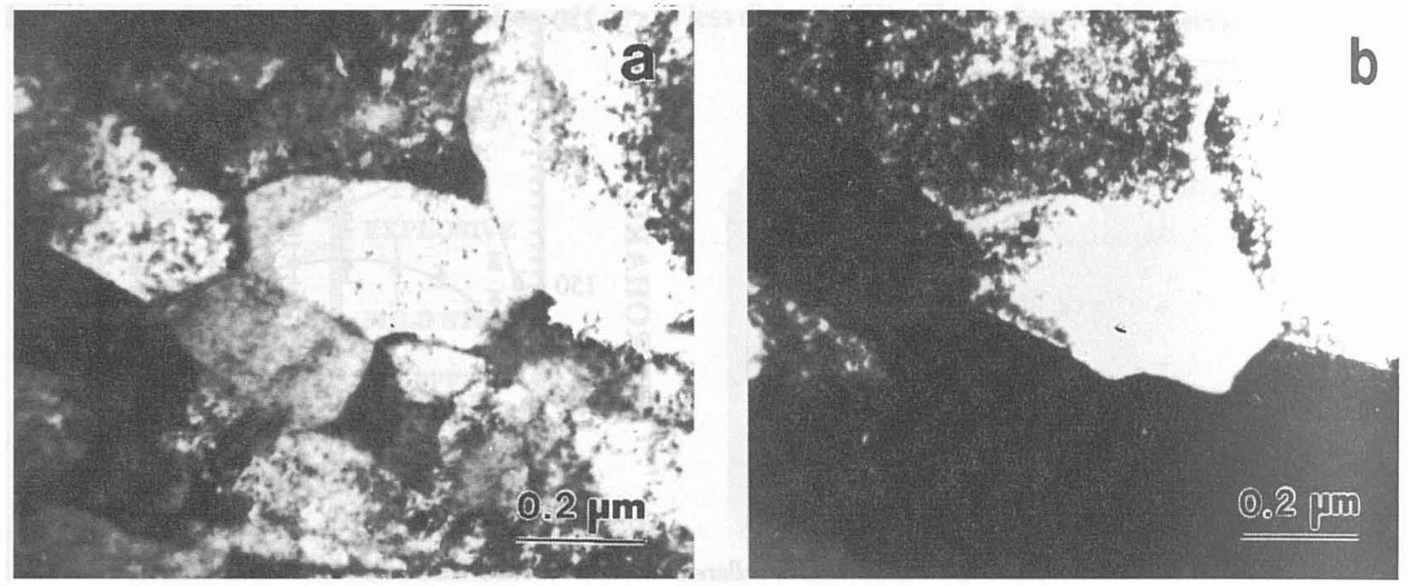

Figure 8 TEM of the region of $<0.5 \mathrm{~mm}$ from center showing recrystallized grains; (a) $\mathrm{BF}$ and $\mathrm{SAD}$; and (b) $\mathrm{CDF}$.

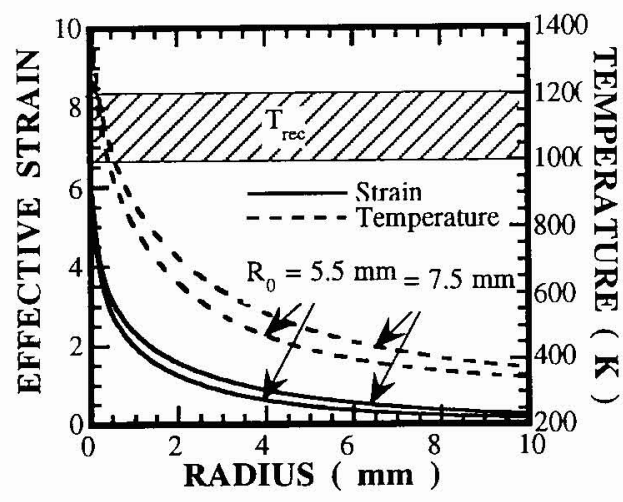

Figure 9 The distributions of strain and temperature for totally collapsed tantalum cylinder.

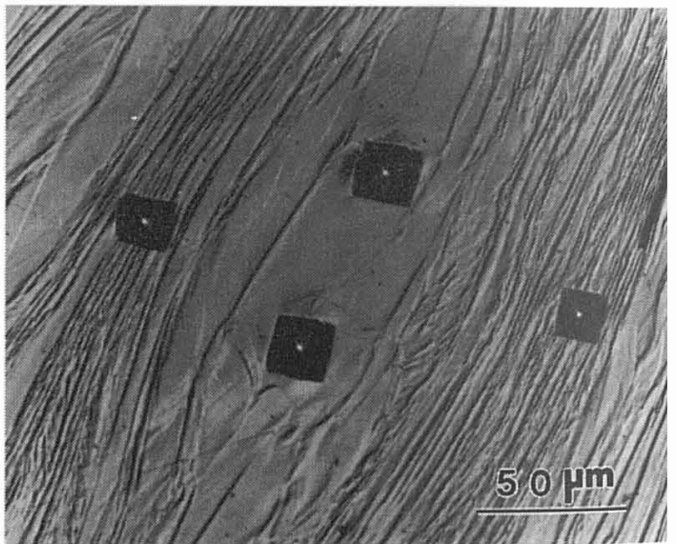

Figure 10 Microindentation markings showing cvidence for grain-scale localization.

\subsection{Prediction of Strain and Temperature}

for, The effective strains as a function of distance from the cylinder axis are given in Figure 9 for initial internal radii of $5.5 \mathrm{~mm}$ (the disk specimens) and $7.5 \mathrm{~mm}$ (the tubular specimens). Effective plastic strains up to 10 can be achieved with this method. Using a modified Johnson-Cook equation [6], the temperature rise as a function of strain is (assuming 90\% conversion of plastic work into heat):

$$
\mathrm{T}=\mathrm{T}_{\mathrm{r}}+\frac{1}{\lambda} \ln \left[\mathrm{e}^{\lambda\left(\mathrm{T}-\mathrm{T}_{\mathrm{r}}\right)}+\frac{0.9 \lambda \varepsilon}{\rho \mathrm{C}_{\mathrm{p}}}\left\{1+\mathrm{C} \log \left(\frac{\dot{\varepsilon}}{\dot{\varepsilon}_{0}}\right)\right\}\left(\sigma_{0}+\frac{\mathrm{B}}{\mathrm{n}+1} \varepsilon^{\mathrm{n}}\right)\right]
$$

The temperature curves in Figure 9 ware computed at the strain rate of $\sim 4 \times 10^{4} \mathrm{~s}^{-1}$, which characterizes the internal wall. Recrystallization temperature is estimated to be between: $1000 \mathrm{~K}[16]$ at the heating rate of $803 \mathrm{~K} / \mathrm{s}$ which resembles the current condition and $1200-1500 \mathrm{~K}$ [17]. The results of the optical microscopy are entirely consistent 
with the temperature predictions. A recrystallized layer of $\sim 0.5 \mathrm{~mm}$ is clearly seen (Figure 3 ), corresponding to the smaller hardness region in Figure 5 and to the region reaching the recrystallization temperature in Figure 9.

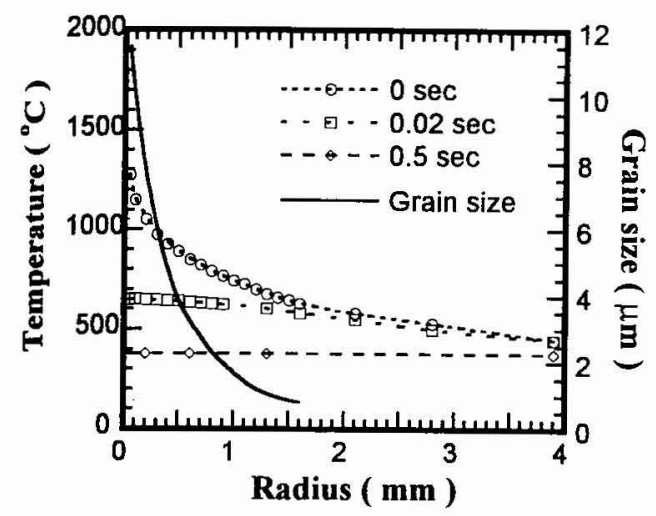

Figure 11 Radial distributions of temperature and grain size computed from grain growth kinetics.

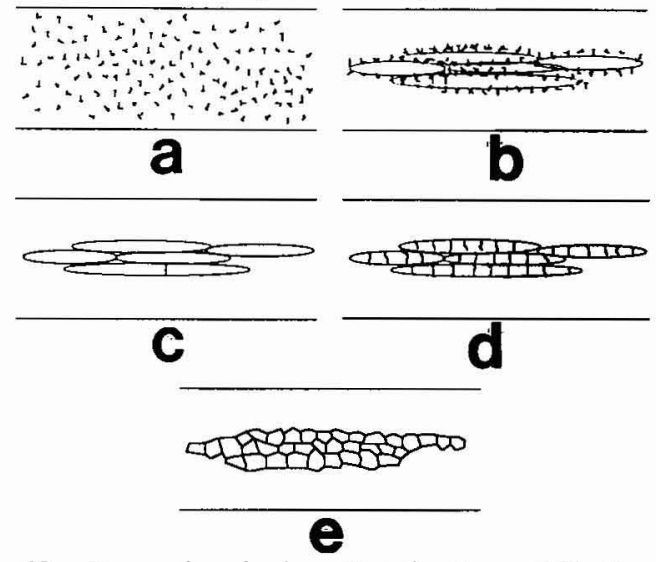

Figure 12 Proposed mechanism of rotational recrystallization; (a) random dislocations; (b) elongated cells; (c) elongated subgrains; (d) subgrain break-up; (e) recrystallized grains.

\subsection{Recrystallization}

Recrystallization occur either dynamically or statically. Static recrystallization can be approximated with grain growth equation [18]:

$$
\Delta \mathrm{d}=\mathrm{k}_{0} \Delta \mathrm{t}^{1 / \mathrm{n}} \exp (-\mathrm{Q} / 2 \mathrm{RT})
$$

where $\Delta d$ is the grain size change, $k_{0}$ a rate constant, $Q$ the activation energy for grain growth, $\Delta t$ the time interval, and $\mathrm{T}$ absolute temperature. The exponent $\mathrm{n}$ was chosen to be 8 . The activation energy can be taken as the activation energy for self-diffusion which was reported to be between $394 \mathrm{~kJ} / \mathrm{mole}$ [13] and $217 \mathrm{~kJ} / \mathrm{mole}$ [19]. The factor $\mathrm{k}_{\mathrm{o}}$ was calculated from the experimental result [13] using $Q=300 \mathrm{~kJ} / \mathrm{mole}$.

The time history of the temperature distribution was computed using a finite-difference method, assuming the initial distribution given by Eqn. 2. The temperature is essentially uniform after $0.5 \mathrm{sec}$. The recrystallized grain size was obtained by numerically integrating Eqn. 3 and assuming the initial grain size to be zero. Figure 11 shows the radial temperature distributions for different times and the radial grain size distribution which is consistent with the measured values in Figure 4. Thus, the recrystallized grains near the inner surface are probably due to static recrystallization.

TEM showed that the regions $\mathrm{R}$ at the tips of the cracks (Figure 3) was composed of the recrystallized grains of $0.1-0.3 \mu \mathrm{m}$ in size (Figure 8). In these small regions, the recrystallization temperature could be reached. However, computation showed that the available time window is not sufficient for grains to grow to the observed size via static recrystallization. Thus, a different mechanism for recrystallization is suggested.

Figure 12 shows the proposed five-stage mechanism based on rotational recrystallization: random dislocations (Stage 1), elongated dislocation cells (Stage 2), elongated subgrains (Stage 3), and relatively equiaxed micrograins (Stage 4). The computation [20] of the energy change in these stages predicts a critical dislocation density, misorientation, and cell size, in accord with experimental observations. The subgrain size, $\delta$, resulting from hightemperature deformation can be related to the applied stress [21] by:

$$
\sigma \delta / \mu \mathrm{b}=\mathrm{K}
$$

where $K \approx 10$ for metals. Derby[22] suggested that it could be applied to rotation recrystallization. For the tantalum in this investigation, applied stress, $\sigma=500 \mathrm{MPa}$, elastic shear modulus, $\mu=69 \mathrm{GPa}$, and Burgers vector, $b=0.2333$ $\mathrm{nm}$. This yields a subgrain size, $\delta=0.3 \mu \mathrm{m}$, consistent with the observations. Thus, it is concluded that dynamic recrystallization by a rotational mechanism can take place in shear localization regions. 


\section{CONCLUSIONS}

1. The thick-wall cylinder method enables controlled and reproducible plastic strains, at strain rates of the order of $4 x$ $10^{4} \mathrm{~s}^{-1}$.

2. The microstructure was observed to evolve in the following sequence: dislocations and dislocation cells for $\gamma<2$ sub-grains (dynamic recovery) for $2<\gamma<6$; micrograins (dynamic recrystallization) for $6<\gamma<10$; and large equiaxed grains (static recrystallization) for $\gamma>10$. This evolution is entirely consistent with the temperature rise predictions using a constitutive equation and experimental observation [6].

3. Profuse ductile cracks were observed propagating radially outward along the bands of highly deformed material These cracks are produced by residual tensile "hoop" stresses during unloading stage.

4. The plastic deformation becomes heterogeneous after a critical strain with the formation of localization at the grain scale. This localization is due to texture softening and to the anisotropy of flow stress. The resulting temperature fluctuation enhances the localization.

5. Both dynamic and static recrystallization are observed. Dynamic recrystallization by a rotational mechanism occurred within the shear localized regions; static recrystallization occurred along the inner radius of the cylinder The grain size of the statically recrystallized region is consistent with the computations based on grain growth kinetics couple with the appropriate calculated cooling path.

\section{Acknowledgments}

This research was supported by the US Army Research Office, University Research Initiative Program (contract DAAL-03-92-G-0108), by ARO Contract DAAH 04-93-G-0261, and by the National Science Foundation Institute for Mechanics and Materials.

Reference

[1] Qiang N., P. Niessen, and R.J. Pick, Mat. Sci. and Eng., A160 (1993) 49.

[2] Gurevitch A.C., L.E. Murr, H.K. Shih, C.S. Niou, A.H. Advani, D. Manuel, and L. Zernow, Mater. Charact., 30 (1993) 201.

[3] Shih H.K., C.-S. Niou, L.E. Murr, and L. Zernow, Scripta Met. et Mat., 29 (1993) 1291.

[4] Murr L.E., C.-S. Niou, and C. Feng, Scripta Met. et Mat., 31 (1994) 297.

[5] Murr L.E., H.K. Shih, and C.-S. Niou, Mater. Charact., 33 (1994) 65.

[6] Meyers M.A., Y.-J. Chen, F.D.S. Marquis, and D. S. Kim, Met. and Mat. Trans, 26A(1995), 2493.

[7] Nesterenko V.F., M.P. Bondar, and I.V. Ershov, in "High-Pressure Science and Technology-1993," eds. S.C Schmidt, J.W. Shaner, G.A. Samara, and M.Ross, AIP Press, NY, 1994, p. 1173.

[8] Nesterenko V.F. and M.P. Bondar, DYMAT J., 1 (1994) 245.

[9] Armstrong R.W., in "Advances in Materials Research," Vol. 5, eds. R.F. Bunshah, Wiley-Interscience, NY 1971, p. 101.

[10] Zerilli F. J. and R. W. Armstrong, J. Appl. Phys. 68 (1990) 1580.

[11] Andrade U.R, M.A. Meyers, K.S. Vecchio, and A.H. Chokshi, Acta Met. et Mat., 42 (1994) 3183.

[12] Gil Sevillano J., P. van Houtte, and E. Aemoudt, Prog. Mater. Sci., 25 (1981) 69.

[13] Vandermeer R. and W.B. Snyder, Jr., Met. Trans. A, 10A (1979) 103.

[14] Mitchell T. E. and W. A. Spitzig, Acta Met., 13 (1965) 1169.

[15] Meyers M. A, G. Subhash, B. K. Kad, and L. Prasad, Mech. of Matls., 17 (1994) 175.

[16] Beckenhauer D., P. Niessen, and P. Pick, J. Matls. Sci. 12 (1993) 449.

[17] Köck W. and P. Paschen, J. of Metals, 41 (No. 10) (1989) 33.

[18] Reed-Hill R.E., Physical Metallurgy Principles, 2nd ed., Van Nostrand, NY, 1973, p. 304.

[19] Krashchenko V.P and V.E. Statsenko, Strength of Matls. 13 (1981) 213.

[20] Meyers M.A., J.C. LaSalvia, V.F. Nesterenko, Y.J. Chen, and B. Kad, in "Proc. ReX 96", Monterey, CA 1996.

[21] Takeuchi S. and A.S. Argon, J. Mater. Sci. 11 (1976) 1547.

[22] Derby B., Acta Met. et Mat. 39 (1991) 955. 